\title{
The Level of Preference of Instant Rice Bran Milk Products Innovation with Various Flavor Variants as Functional Food
}

\author{
Saifuddin Sirajuddin ${ }^{1 *} \mathbb{D}$, Masni Masni ${ }^{2} \mathbb{D}$, Abdul Salam $^{1} \mathbb{D}$ \\ ${ }^{1}$ Department of Nutrition, Universitas Hasanuddin, Makassar, Indonesia; ${ }^{2}$ Department of Reproductive and Family Health, \\ Universitas Hasanuddin, Makassar, Indonesia
}

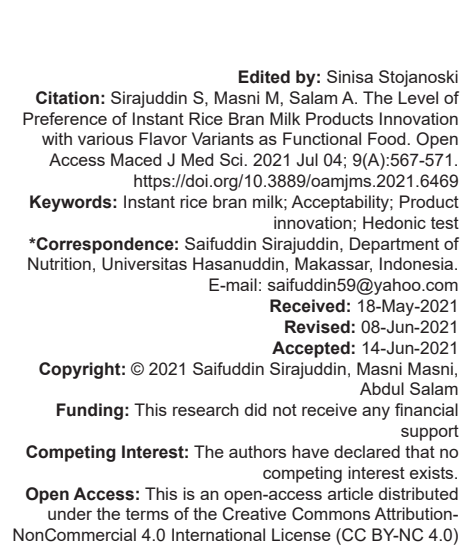

\section{Introduction}

Rice bran is now widely used as food. Some countries in the world, such as the United States and Japan, have developed rice bran as a food product, for example, as breakfast cereals and rice bran oil [1]. Opportunities for developing rice bran as functional food in Indonesia are also very open, this is because rice production in 2020 amounted to 54.65 million tons of milled dry unhulled rice (GKG), an increase of 45.17 thousand tons or $0.08 \%$ compared to 2019 which amounted to 54.60 million tons of GKG [2]. Increasing the amount of production and information about the nutritional content of rice bran flour which is very useful, it is necessary to make efforts to diversify rice bran products.

At present, there are many types of beverage products such as soy milk, corn milk, and whole-grain milk. Rice bran has been used as a food ingredient such as bread products, snacks, and high protein powder supplements, but the use of rice bran in instant healthy drinks such as rice-based milk products is still lacking [1]. One form of functional food that is popular is in the form of drinks [3]. This is because the processing in making drinks is not much so that the nutritional content in drinks is maintained. In addition, functional food in the form of drinks is also considered practical.

Production of drinks from rice bran into functional drinks is one interesting alternative to the added value of rice bran itself. In addition to increasing its value, rice bran-related products are also still lacking in the community [1]. The main antioxidant content of bran is $Y$-oryzanol can reduce blood glucose and cholesterol [4]. Product evaluation before it is marketed needs to be done to determine the level of consumer preference for the product including color, aroma, taste, texture, and overall assessment of the product. Testing of food is not only seen from the chemical aspect but also must be seen in terms of taste and aroma [5]. Therefore, organoleptic tests need to be known to find out how far instant rice bran products are made preferred by consumers. Organoleptic test is the result of psychological reactions in the form of responses or impressions of quality by a group of people called panelists [6]. Panelists are people whose job is to evaluate the nature or quality of ingredients based on subjective impressions. The grouping of panelists into six groups, namely, individual tasting panelists, limited tasting panelists, trained panelists, moderately trained panelists, and consumer panelists. For food testing using panelists rather trained or not trained often done, 
because it does not require panelists who have high sensitivity and in this case can use students.

The evaluation of instant bran milk products carried out in this study is the organoleptic testing method, namely, acceptance test and preference test or hedonic test on untrained panelists.

Trained panelists consist of 15-25 people who have good enough sensitivity and the requirements to become a trained panelist must be preceded by selection and exercises while the untrained panel consists of 25 lay people who can be selected based on gender, ethnicity, social level, and education. An untrained panel is only allowed to assess simple organoleptic properties such as preference traits, and may not be used in differentiation tests. Acceptance test aims to determine someone's assessment of the nature or quality of ingredients that cause consumers to like the food [7]. In this case, the panelists put forward a personal response that is the impression associated with liking or whether or not a happy response to the sensory nature or quality of the food or drink being valued. The criteria of the hedonic test used in this study were assessed from the aroma, texture, color, taste, and overall impression of the product.

The purpose of this study was to determine the acceptability of bran-based dairy products as a dairy product innovation through hedonic testing in accordance with the sensory properties of color, aroma, taste, texture, and overall impression of the product by untrained panelists.

\section{Methods}

The research method used is an experiment, in this case, we want to know the effect of certain treatments on others under controlled conditions. This is done through a product preference test (hedonic test), this test uses a Likert scale with five choices, namely, 1 = like; 2 = rather like; 3 = neutral; 4 = rather not like; and $5=$ do not like it. Samples of rice bran were assessed by 32 untrained panelists. After the acceptance test is carried out, data processing is carried out to determine whether or not dairy flour-based milk products are acceptable.

The samples to be tested were five kinds of instant rice bran with different flavorings (chocolate, vanilla, melon, orange, and original), each weighed as much as $15 \mathrm{~g}$ and brewed with hot water $\left(90^{\circ} \mathrm{C}\right)$. Furthermore, the sample is distributed into organoleptic testing cups that have been equipped with a code with a volume of $5-15 \mathrm{ml}$ per glass. Each code represents one formula of instant rice bran (Figure 1). Then, the sample is presented in the testing room. Samples were presented simultaneously; five samples were tested by one panelist in an organoleptic testing booth. Panelists were given an explanation of the assessment forms and other important matters when conducting organoleptic tests. Panelists were asked to write a hedonic scale response on the form provided by ticking the box according to the feeling he felt/assessed. In taste testing, panelists are sure to always drink water before moving from one formula to another in giving an impression.

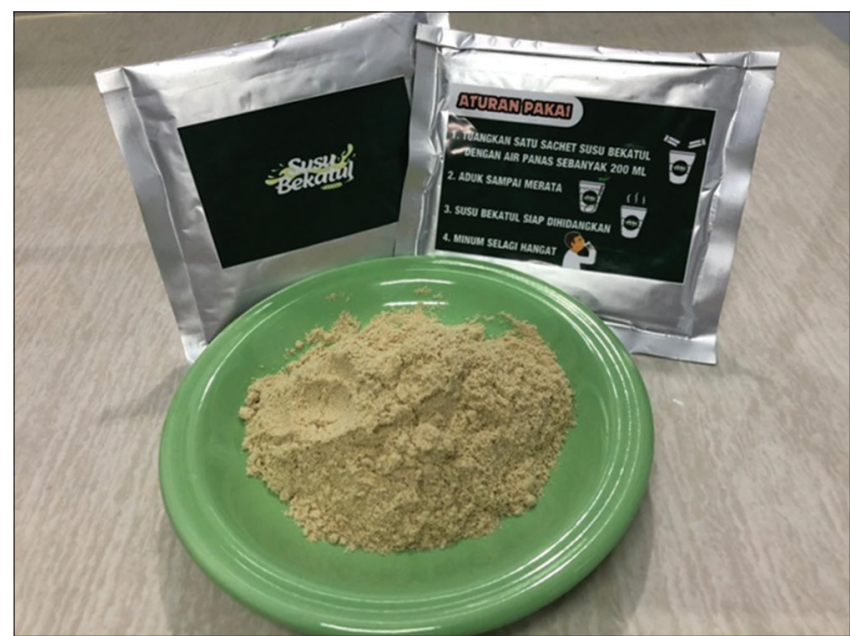

Figure 1: Samples of rice bran milk

The instrument used in this study was a questionnaire for hedonic testing using a Likert scale in the form of a checklist. In the Likert scale, the research variables are measured and translated into indicators of the level of liking consisting of five levels, namely, likes, likes, neutral, somewhat dislikes, and dislikes in every aspect of product sensory assessment (texture, color, aroma, taste, and overall assessment).

In analyzing the data, the hedonic scale is transformed into a number scale so that the data can be analyzed using statistical analysis. The collected data were analyzed descriptively and analytically using a computer. To find out whether there is a difference in preference scores for dairy products based on flavor variants, the Kruskal-Wallis test is used and if there are significant differences, a further test is done using the Mann-Whitney U-test and the SPSS program.

\section{Results and Discussion}

Hedonic test is a test conducted using human senses through sensory stimulation, carried out to determine the level of consumer preferences for a product. In this test, 32 untrained panelists were involved to state their level of preference based on five criteria, namely, color, aroma, taste, texture, and overall impression by rating: Likes, somewhat likes, neutral, somewhat dislikes, and dislikes.

The hedonic test results of instant rice bran products are as follows Figure 2. 


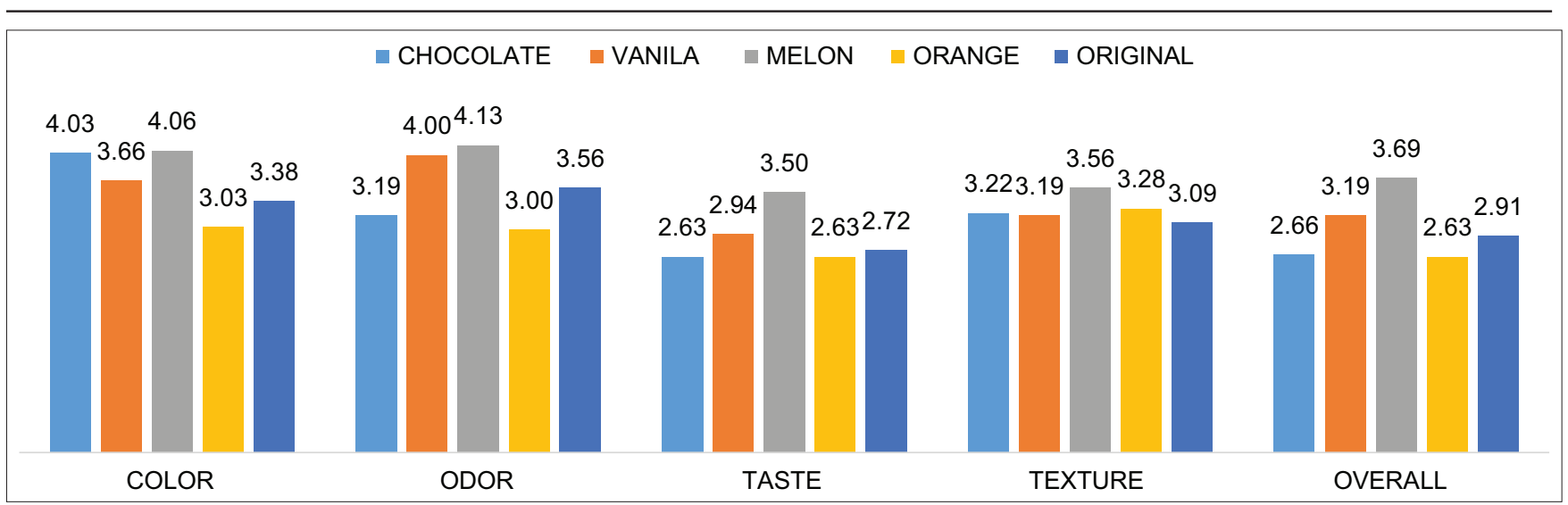

Figure 2: Results of hedonic tests of instant rice bran milk products with flavors variant

Table 1 shows that overall panelist assessment of instant rice bran milk products shows that rice bran milk that uses melon flavoring has the highest score (3.69) and the lowest is using orange flavoring (2.63). The most preferred product is milk that uses melon flavoring. There were differences in the average results of the panelist assessment of each product based on color, odor, and overall rating ( $p<0.05)$, while based on taste and texture, there is no difference $(p>0.05)$. However, if we focus on the overall panelist rating score for instant rice bran milk products with flavor variants, with the consideration that this may represent other sensors, then it appears that the panelist assessment score or the highest level of preference is for dairy products with melon flavor.

Table 1: Average score of the results of the panelist assessment of instant rice bran milk product

\begin{tabular}{llllll}
\hline Type of rice bran milk & Color & Odor & Taste & Texture & Overall \\
\hline Chocolate & 4.03 & 3.19 & 2.63 & 3.22 & 2.66 \\
Vanilla & 3.66 & 4.00 & 2.94 & 3.19 & 3.15 \\
Melon & 4.06 & 4.13 & 3.50 & 3.56 & 3.69 \\
Orange & 3.03 & 3.00 & 2.63 & 3.28 & 2.63 \\
Original & 3.38 & 3.09 & 2.72 & 3.09 & 2.91 \\
p & 0.006 & 0.001 & 0.094 & 0.684 & 0.001 \\
\hline
\end{tabular}

Presentation of panelists' preference level for instant rice bran milk products using flavor variants in the form of spider webs shows more clearly that rice bran uses melon flavor most favored by panelists from all aspects of assessment, namely, color, aroma, taste, texture, and overall assessment

Hedonic test is a test in organoleptic sensory analysis that is used to find out the magnitude of the quality difference between several similar products by giving an assessment or score of certain properties of the product to determine the level of liking of a product [8]. The preference test is also called the hedonic test. Panelists were asked their personal responses about likes or vice versa (dislike). Besides, the panelists expressing happy, like, or reverse responses, they also expressed their level of liking. This favorite level is called the hedonic scale. For example, in the case of "likes" can have a hedonic scale such as like and somewhat like, otherwise if the response is "dislike" can have a hedonic scale such as somewhat dislike and dislike, there is also a response called neutral, which is not like but also not dislike (neither like nor dislike). The hedonic scale can be stretched or collapsed according to the desired scale range. The hedonic scale can also be changed to a numerical scale with a quality score according to the level of preference. With this numerical data, statistical analysis can be done.

In practice, the hedonic scale can be used to determine whether there is a difference in the level of panelist preference for a product, so hedonic tests are often used to assess organoleptically against similar commodities or development products [9]. Hedonic test is widely used to assess the final product. The acceptance test involves assessing the nature or quality of a material that causes people to like it. The acceptance test cannot be used to predict revenue in marketing, so if a convincing test result is obtained, it cannot be ensured that the product will sell well in the market, so other tests must be used in the follow-up, for example, consumer testing. In the hedonic test, panelists were asked their personal responses about likes or vice versa. These favorite levels are called the hedonic scale. In the analysis, the hedonic scale is transformed into a numerical scale with ascending numbers according to the level of preference. With this numerical data, statistical analysis can be done.

In conducting hedonic tests, panelists play a very important role to assess product quality specifications subjectively. The minimum number of trained panelists in a single test is six people, while for untrained panelists is 30 people. In this study, 32 untrained panelists were used so that they met the requirements. The panelists assessed five types of rice dairy products based on flavor variants, namely, chocolate, vanilla, orange melon, and no taste (original). From the results of the panelists' assessment, the use of melon flavorings had the highest assessment on taste, texture, and overall attributes followed by bran milk using chocolate and orange flavorings.

\section{Color}

Color in food products has an important role as an attraction, identification and is one of the attributes of product appearance that often determines consumer 
acceptance of the product as a whole. Color is a quality factor that most attracts the attention of consumers and can give an impression, whether the product is liked or not. The hedonic test results on the color of instant rice bran milk based on the flavor variants used can be shown in Figure 1, showing that the highest preference level based on panelists' assessment is on instant rice bran using melon flavor and the lowest is milk using orange flavor. This means that the most preferred formula in terms of color is using melon flavor.

\section{Odor}

As with color, odor determines consumer acceptance of the product, even more so because the aroma is very influential when consumers will taste a product, it can even be a determinant before someone wants to try the product. The tongue can taste other flavors according to the aroma given to a food product [10]. Odors plays an important role as a flavoring, which is used in the food and beverage industry to improve taste and generally increases the attractiveness of these food products [11]. The hedonic test results presented in Figure 1 show that rice bran milk using melon flavor is the most preferred by panelists (average score $=4.13$ ) and the least is rice bran milk with orange flavor (mean score $=3.0$ ).

\section{Taste}

Taste is a factor that determines food quality, which is determined by taste compounds contained in the product. This flavor compound will cause the sensation of taste (sweet, bitter, sour, and salty) and aroma. Taste compounds are compounds that can affect the senses of the body, for example, the tongue as a sense of taste, besides that taste can evoke a sense through the aroma that is spread, more than just the taste of the product that is salty, bitter sweet, and so on. The hedonic test results presented in Figure 1 show that the highest preference score (3.50) is for rice bran milk using melon flavor and the lowest is using chocolate and orange flavor (2.94). Other studies have shown that bran drinks with too much cocoa powder have an unwelcome aroma and the most preferred drink is bran drinks which have the same ratio of bran and cocoa powder [12]. As for the research of Wulandari and Handarsari (2010) on biscuits with the addition of bran, it was stated that there was a difference in the aroma of each addition of bran to biscuits, biscuits with $0 \%$ bran had a good preference for biscuits with $5 \%$ bran, while biscuits with $15 \%$ bran have a better preference level than biscuits with $10 \%$ bran [13]. Adanya aroma khas bekatul disebabkan oleh kandungan minyak tokoferol (komponen volatif) pada bekatul [14].

\section{Texture}

Texture is a characteristic of a material due to a combination of physical properties which includes the size, shape, amount, and forming elements of the material that can be felt by the sense of taste and touch, including the senses of the tongue and vision. The texture of a food product includes thickness, semisolid, or solid is influenced by the water content, fat, the amount, and type of carbohydrate of the product. Panelist assessment results presented in Figure 1 show that rice bran milk using melon flavor has the highest score (3.56) and the lowest score on milk that does not use flavor (original), this means that the most preferred in terms of texture is bran milk with melon flavorings. Texture in foodstuffs is one of the quality attributes, because texture is an important factor influencing consumer perceptions of the quality of the foodstuff. Other studies have shown that making corn milk with the addition of CMC results that the higher the CMC concentration, the water, dissolved solids, and insoluble solids contained in corn milk are thicker and more stable, which causes the viscosity value or viscosity to increase [15].

The implication or use of this product is that it can be used as a health drink because it contains gamma oryzanol as an antioxidant which can play a role in neutralizing free radicals that interfere with the performance of pancreatic beta-cells [16]. Therefore, gamma-oryzanol contained in bran milk can be useful for lowering blood sugar levels or as an antidiabetic [17]. In addition, with the development of rice bran milk, it can increase the economic value of rice bran which has been used only as animal feed. Other studies have also shown that rice bran milk can be used as nutritional supplements for the control of hyperglycemia and body weight of overweight and diabetic individuals [18].

\section{Conclusion}

There were differences in the average results of the panelist assessment of each product based on color, odor, and overall rating ( $p<0.05)$, while there is no difference based on taste and texture $(p>0.05)$. However, if we focus on the overall panelist rating score for instant rice bran milk products with flavor variants, with the consideration that this may represent other sensors, then it appears that the panelist assessment score or the highest level of preference is for dairy products with melon flavor.

\section{References}

1. Issara U, Rawdkuen S. Rice bran: A potential of main ingredient in healthy beverage. Int Food Res J. 2016;23(6):2306-18.

2. BPS. Luas Panen dan Produksi Padi di Indonesia 
2020; 2021. Available from: https://www.bps.go.id/ pressrelease/2021/03/01/1855/luas-panen-padi-pada-tahun2020-mengalami-penurunan-dibandingkan-tahun-2019sebesar-0-19-persen-dan-produksi-padi-pada-tahun-2020mengalami-kenaikan-dibandingkan-tahun-2019-sebesar-008-persen.html. [Last accessed on $2021 \mathrm{Apr}$ 29]. https://doi. org/10.31219/osf.io/yftg7

3. Rezai G, Teng PK, Mohamed Z, Shamsudin MN. Functional food knowledge and perceptions among young consumers in Malaysia. Int J Econ Manag Eng. 2012;6(3):307-12.

4. Moongngarm A, Daomukda N, Khumpika S. Chemical compositions, phytochemicals, and antioxidant capacity of rice bran, rice bran layer, and rice germ. APCBEE Proc. 2012;2:73-9. https://doi.org/10.1016/j.apcbee.2012.06.014

5. Sinesio F. Sensory evaluation. In: Worsfold P, Townshend A, Poole C, editors. Encyclopedia of Analytical Science. $2^{\text {nd }}$ ed. Oxford: Elsevier; 2005. p. 283-90. Available from: https://www. sciencedirect.com/science/article/pii/b0123693977005616. [Last accessed on 2021 Apr 29]. https://doi.org/10.1016/ b0-12-369397-7/09003-8

6. Ana A, Subekti S, Hamidah S, Komariah K. Organoleptic test patisserie product based on consumer preference. IOP Conf Ser Mater Sci Eng. 2017;180:012294. https://doi. org/10.1088/1757-899x/180/1/012294

7. Bos C, van der Lans IA, van Rijnsoever FJ, van Trijp HC. Understanding consumer acceptance of intervention strategies for healthy food choices: A qualitative study. BMC Public Health. 2013;13:1073. https://doi.org/10.1186/1471-2458-13-1073 PMid:24225034

8. Singh-Ackbarali D, Maharaj R. Sensory evaluation as a tool in determining acceptability of innovative products developed by undergraduate students in food science and technology at The University of Trinidad and Tobago. J Curr Teach. 2014;3(1):10. https://doi.org/10.5430/jct.v3n1p10

9. Mihafu FD, Issa JY, Kamiyango MW. Implication of sensory evaluation and quality assessment in food product development: A review. Curr Res Nutr Food Sci J. 2020;8(3):690-702. https:// doi.org/10.12944/crnfsj.8.3.03

10. InformedHealth. How Does Our Sense of Taste Work? Germany: Institute for Quality and Efficiency in Health Care (IQWiG); 2016.

11. Morquecho-Campos $\mathrm{P}$, de Graaf K, Boesveldt S. Smelling our appetite? The influence of food odors on congruent appetite, food preferences and intake. Food Qual Prefer. 2020;85:103959. https://doi.org/10.1016/j.foodqual.2020.103959

12. Hadi A, Siratunnisak N. The effect of adding cocoa powder to the physical, chemical, and organoleptic properties of instant bran instant drink. AcTion Aceh Nutr J. 2016;1(2):121-9. https:// doi.org/10.30867/action.v1i2.22

13. Wulandari $M$, Handarsari $E$. The influence of addition of rice bran to protein consentration and organoleptic characteristic. J Pangan Gizi. 2010;1(2):55-62.

14. Amir $\mathrm{Y}$, Sirajuddin $\mathrm{S}$, Syam A. Preference of bran milk as functional food. HJPH. 2020;1(1):16-25.

15. Harianja $\mathrm{CH}$, Rusmarilin $\mathrm{H}$, Yusraini E. Maize Milk Production With Enriched Germinated Green Beans and Addition of CMC As Stabilizer. Jurnal Rekayasa Pangan dan Pertanian. 2015;3(1):26-33.

16. Juliano C, Cossu M, Alamanni MC, Piu L. Antioxidant activity of gamma-oryzanol: Mechanism of action and its effect on oxidative stability of pharmaceutical oils. Int J Pharm. 2005;299(1-2):146-54. https://doi.org/10.1016/j.ijpharm.2005.05.018

PMid: 16005170

17. Cheng HH, Ma CY, Chou TW, Chen YY, Lai MH. Gammaoryzanol ameliorates insulin resistance and hyperlipidemia in rats with streptozotocin/nicotinamide-induced Type 2 diabetes. Int J Vitam Nutr Res. 2010;80(1):45-53. https://doi. org/10.1024/0300-9831/a000005

PMid:20533244

18. Sirajuddin S, Masni, Salam A. The effect of giving rice bran milk on blood glucose levels and body weight in hyperglycemic primary school teachers in Makassar city. Int J Pharm Res. 2021;13(1):2972-8. https://doi.org/10.31838/ ijpr/2021.13.01.438 